US Army Corps of Engineers $s_{\circledast}$

Engineer Research and

Development Center

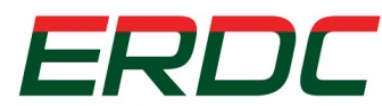

INNOVATIVE SOLUTIONS for a safer, better world

Engineer Site Identification for the Tactical Environment (ENSITE)

\title{
Endangered Cultural Heritage: Global Mapping of Protected and Heritage Sites
}

Kathryn O. Fay and George W. Calfas

July 2017

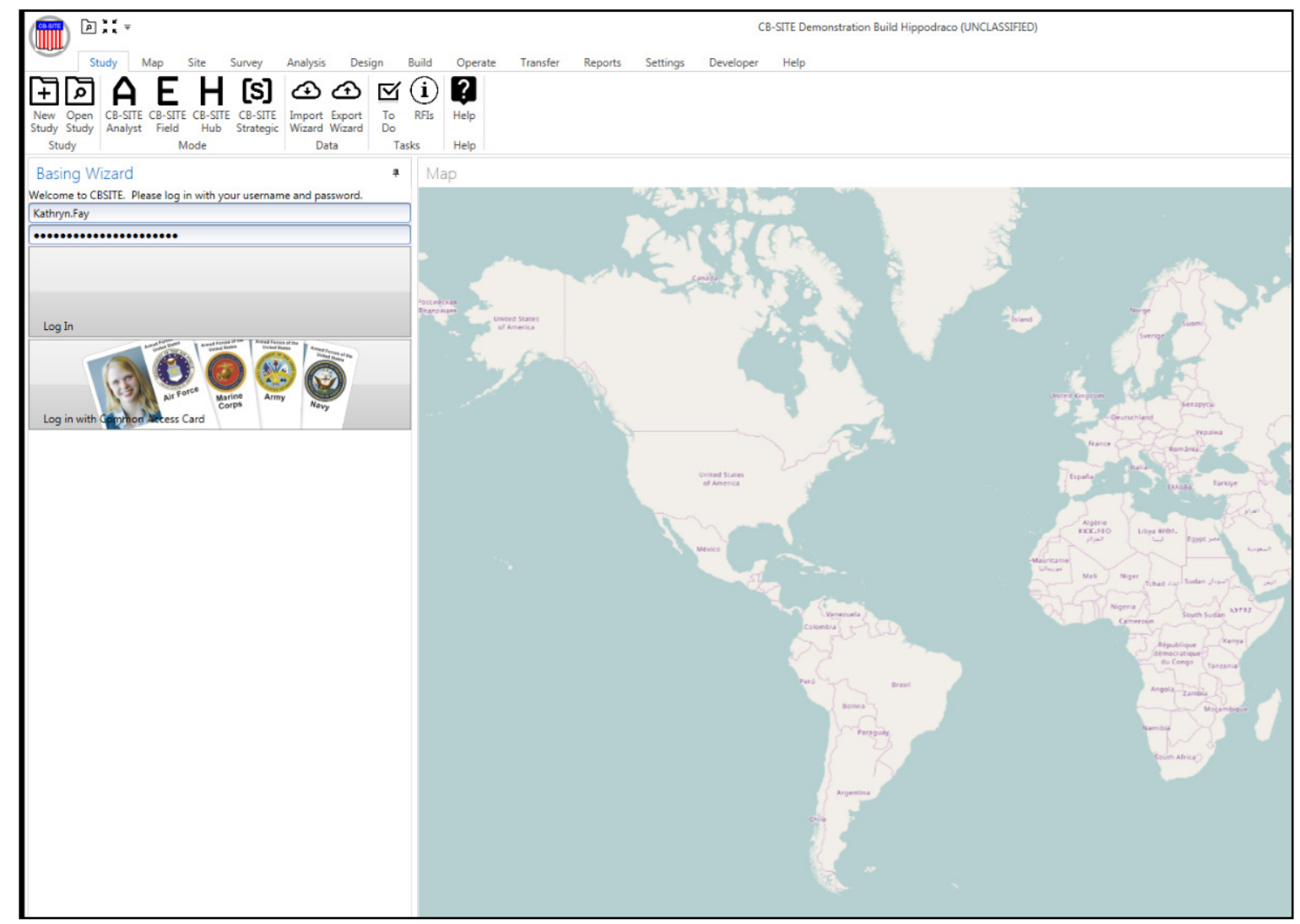


The U.S. Army Engineer Research and Development Center (ERDC) solves the nation's toughest engineering and environmental challenges. ERDC develops innovative solutions in civil and military engineering, geospatial sciences, water resources, and environmental sciences for the Army, the Department of Defense, civilian agencies, and our nation's public good. Find out more at www.erdc.usace.army.mil.

To search for other technical reports published by ERDC, visit the ERDC online library at http://acwc.sdp.sirsi.net/client/default. 


\section{Endangered Cultural Heritage: Global Mapping of Protected and Heritage Sites}

Kathryn O. Fay and George W. Calfas

Construction Engineering Research Laboratory

U.S. Army Engineer Research and Development Center

2902 Newmark Drive

Champaign, IL 61822

Final report

Approved for public release; distribution is unlimited.

Prepared for Assistant Secretary of the Army for Acquisition, Logistics, and Technology (ASA(ALT))

103 Army Pentagon

Washington, DC 20314-1000

Under Project No. 455009, "Contingency Base - Site Identification for the Tactical Environment" 


\section{Abstract}

Through its many global missions, the United States Army has not always recognized nor allocated sufficient resources to protect cultural heritage sites in active military zones. This pattern is changing, however, especially as a result of incidents that occurred during antiterrorism military missions in Iraq and Afghanistan. To change that pattern, the Engineer Research and Development Center of the U.S. Army Corps of Engineers is designing an interactive mapping program that provides information on possible suitable locations for future military movement and campsites. As part of that work, and in light of past frictions between military actions and cultural heritage preservation, both cultural anthropologists and archaeologists have contributed information about the locations of sacred sites, heritage landscapes, archaeological remains, and other locations of cultural and religious importance. These locations are then noted within the mapping program as areas that are culturally unsuitable for military movement or settlement, similar to noting areas that would be logistically or environmentally unsuitable. This paper discusses the project and its plans for implementation, in hopes of decoupling the past link between military action and unintentional damage or destruction of cultural heritage sites as well as expanding the knowledge base on these issues in the military community.

DISCLAIMER: The contents of this report are not to be used for advertising, publication, or promotional purposes. Citation of trade names does not constitute an official endorsement or approval of the use of such commercial products. All product names and trademarks cited are the property of their respective owners. The findings of this report are not to be construed as an official Department of the Army position unless so designated by other authorized documents. 


\section{Contents}

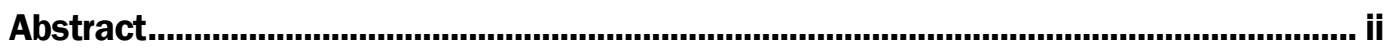

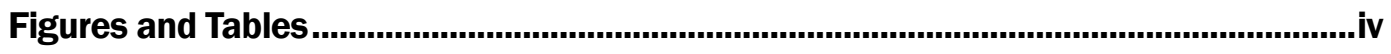

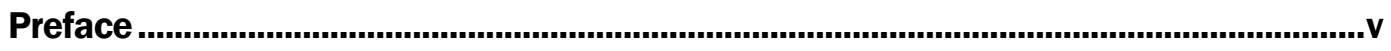

Foreword .......................................................................................................................vi

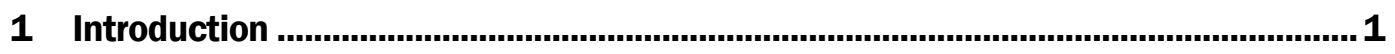

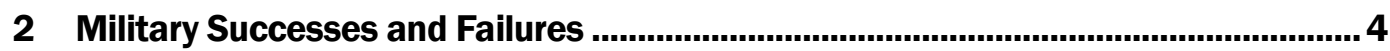

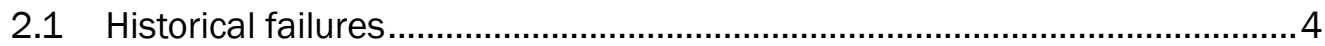

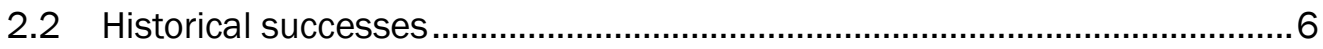

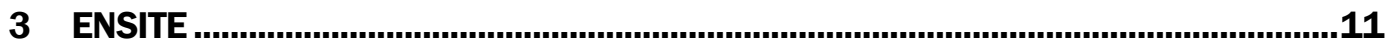

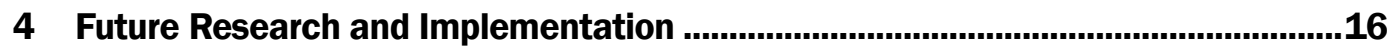

References......................................................................................................................18

Report Documentation Page 


\section{Figures and Tables}

\section{Figures}

Figure 1. Screenshot of ENSITE main dashboard (ERDC-CERL).

Figure 2. Screenshot of ENSITE initial process options for site-selection process, using Dhaka, Bangladesh, as a test area (ERDC-CERL).

Figure 3. The metropolitan area of Dhaka, Bangladesh, used as a high population density test area for the identification and mapping of heritage sites within the ENSITE program. Identified heritage sites and their surrounding buffer zones are highlighted in red (ERDC-CERL).

\section{Tables}

Table 1. Some types of heritage sites included in the ENSITE program as protected, no-build areas. 


\section{Preface}

This study was conducted for the Department of the Army under applied research program T45, Project 45509, "Contingency Base Site Evaluations for Tactical Environment.” The technical monitor was Mr. Kurt Kinnevan, CEERD-CZT.

The work was performed by the Environmental Processes Branch (CNE) of the Installations Division (CN), U.S. Army Engineer Research and Development Center, Construction Engineering Research Laboratory (ERDCCERL). At the time of publication, Mr. Garth Anderson was Chief, CEERDCNE; Ms. Michelle Hanson was Chief, CEERD-CN; and Mr. Kurt Kinnevan, CEERD-CZT, was the Technical Director for Adaptive and Resilient Installations. The Deputy Director of ERDC-CERL was Dr. Kirankumar Topudurti, and the Director was Dr. Ilker Adiguzel.

The Commander of ERDC was COL Bryan S. Green, and the Director was Dr. David W. Pittman. 


\section{Foreword}

The contents of this report represent a version of the authors' paper that was submitted to the Society for American Archaeology 82 ${ }^{\text {nd }}$ Annual Meeting held in Vancouver, BC, Canada, from 29 March-2 April 2017. The content has not been changed in length or substance, but merely edited for compliance with Engineer Research and Development Center's publishing standards.

Jean S. Noellsch

Writer/Editor (CTR)

Information Science and Knowledge Management Branch

Engineer Research and Development Center 


\section{Introduction}

The U.S. military has an unfortunate historical pattern of unintentionally damaging the cultural and natural heritage sites of the nations it operates within. These damaging incidents, more often involving the U.S. Army due to its size and the nature of its ground-based missions, have received more public attention as of late due to multiple incidents within the recent campaigns in Iraq and Afghanistan. However, safeguarding heritage sites during wartime has been a concern of most cultures throughout recorded history. This problem is one that nations still deal with today, whether they are fighting inter- or intra-state conflicts.

Individuals from within and outside the U.S. Army have been pushing Army officials to recognize the problem and begin measures to correct it. In addition to new Army regulations, expanding no-strike lists for aerial assaults, and pre-deployment training courses for some soldiers, the Army Corps of Engineers' Engineer Research and Development Center, Construction Engineering Research Laboratory (ERDC-CERL) is developing a new tool that will assist with avoiding damage to the host nation's heritage sites when conducting for maneuvers and constructing new, overseas Deployed Force Infrastructure (DFI). This tool is a computerized mapping program that aids in selecting the location (site) for DFI elements. These locations are designed to be of short-term use for housing personnel and conducting operations, but on occasion the sites may become permanent installations through official transfer to the host nation.

This new tool is known as Engineer Site Identification for the Tactical Environment (ENSITE), and it contains multiple user-directed overlays on a base geographical map, offering a variety of information pertinent to a military unit's needs in choosing a location for new DFI. ENSITE is designed to be, in essence, a one-stop shop for such information. Information relevant to watersheds, floodplains, building material availability, roadways, and elevation are available to ENSITE users, in addition to the independent layer containing the locations of all natural and cultural heritage sites in the chosen area. This added layer ensures that all known heritage areas will always be marked as off-limits, no-build zones for Army construction. Prohibiting building within the boundaries of any known heritage site, or within an ENSITE-added 100-meter buffer zone around 
these sites, provides much more protection for these sites than has generally occurred in the past.

Proper strategic planning for DFI placement will consider environmental, logistical, and cultural factors. Protection of sensitive sites should not be dismissed as unimportant or superfluous to the Army's mission. Rather, such protection is a boon to both the Army and the host nation (Kila 2012, 3). Proper consideration of the cultural and natural heritage assets of a host nation has several benefits for the Army, while either occupying the host with a military force or assisting it with humanitarian aid and disaster relief. Proper respect and care for heritage properties creates not only a better relationship with the host nation and its people, but also a better international reputation for the Army (Kila and Herndon 2014).

Cultivating respectful relations and interactions with the local population can lead to other force multipliers that are beneficial to the intended mission (Kila 2011, 324; Kila 2013, 15; White and Livoti 2013, 196). Operating on either a military or humanitarian mission will be much easier when a local populace does not fear the Army will disrespect, damage, or destroy the objects and places which are important and sacred to them (Hallett 2013, 196; Kila 2012, 27). Lastly, proper safeguarding, care, and avoidance of heritage sites brings the Army into compliance with multiple international treaties the United States government has signed. Adhering to a policy of protection for heritage sites ensures that neither commanding officers nor the US government will have to answer for violations of international treaty law (Van der Auwera 2013a, 43; 2013b, 1; 2014, 3).

The ENSITE program will fill a gap in the Army's planning for overseas missions, allowing for proactive cultural property protection measures relating to the placement of DFI. Presently, most of the Army's admittedly few plans, programs, and resources dealing with cultural property and heritage sites are reactive measures, utilized only if and when damage has occurred. As evidenced by recent historical events in Iraq and Afghanistan, reactive measures alone are not sufficient to deal with cultural property and heritage site issues that will arise when deploying Army units overseas and then moving those units or re-siting the related DFI. Stronger, more substantive plans are needed, not only to deal with potential damage but to prevent it from occurring at all. Both proactive and reactive measures should be in place, and more personnel and training need to be given to 
those measures. Inclusion of heritage site location data within the ENSITE program is one of the first steps toward accomplishing this goal. 


\section{Military Successes and Failures}

\subsection{Historical failures}

The military has an acknowledged historical pattern of damage to cultural and natural heritage sites. This damage, however, has been largely unintentional and typically has resulted from ignorance of the sites' existence or of their importance to the local community and/or culture within the host nation. This unfortunate pattern has been highlighted recently by several events during the campaigns in Iraq and Afghanistan, due to the large scale of those conflicts and the preponderance of heritage sites in both countries.

Military action or movement, but especially open conflict, can cause irreparable damage to cultural and natural heritage sites. Moving a large number of people, heavy vehicles, and the necessary infrastructure to support them can greatly alter a landscape, as can the obviously destructive power of small- or large-arms fire and bombardment. These actions result in several main types or causes of damage to heritage sites within a conflict area, including the following: (a) intentional damage, destruction, or theft; (b) unintentional collateral damage from targeting legitimate military objectives; (c) unintentional damage resulting from ignorance of location or importance; and (d) looting sites and institutions to obtain objects of value (Gerstenblith 2009, 1; Van der Auwera 2013a, 43).

Currently when the Army goes abroad, there is not an active office or program with full-time staff and funding that is in charge of managing cultural and natural resources in host nations (Jackson 2008, 54). Recent initiatives for heritage site preservation within the military branches have essentially been relegated to voluntary duties for deployed personnel in addition to their regular duties (Pinckney 2010; Rush 2012a). International treaty law and U.S. law hold the military accountable for heritage sites during conflict abroad, thus providing some guidelines and considerations for the protection of sites that are important to the culture and history of the host nation. Both sets of laws, however, are somewhat vague on exactly what considerations must be taken and where the ultimate responsibility lies for protection, conservation, and preservation. It is clear that there is a legal responsibility to at least consider the protection of heritage 
sites before taking action (Jackson 2008); however, considering that protection is a requirement, it is a requirement that has been not entirely fulfilled in recent history.

There has been a great deal of coverage in both the popular and academic press of the damage to heritage sites that occurred within the last decade, during the conflicts in Iraq and Afghanistan. Unfortunately, those reports have provided the most recent examples of missteps by the militaries of several countries (including the United States) in handling the heritage sites and cultural property of an occupied country. When the invasion of Iraq began in 2003, the United States had not yet signed the Hague Convention of 1954, so it was not as strictly bound to its statutes, other than the Convention's statutes being considered as accepted international law. There was little consideration given to the heritage sites that would be affected by the invasion of Iraq, especially given the complicated and dangerous conflicts throughout the country.

Likely the most infamous damage in Iraq was the looting of the National Museum in Baghdad (Bahrani 2003; Emberling and Hanson 2008; Huot 2008; Isakhan 2013; Stone 2009). Looting took place during and shortly after the invasion of the city, before troops were dispatched to guard the area (Gibson 2009, 335). Subsequent investigations and operations have seen some of the stolen artifacts returned or confiscated, including some of the most famous pieces which were taken, but hundreds if not thousands still remain missing. In addition to the museum, many major archaeological sites have undergone looting during the occupation of Iraq, when these sites' typical security protections were not in place (Emberling and Hanson 2008; Isakhan 2013, 220; Stone 2009). This type of destruction and erasure of cultural history erodes cultural and national identity (Bahrani 2003; Isakhan 2013, 220) and harms one of the methods of economic recovery after an area's occupation or conflict-tourism (Kila 2011, 312).

The other major source of site damage was base construction that was located on or very near important natural or cultural sites. The ancient site of Babylon is the most well-known example, where a large base built on the perimeter of the main ruins has endangered the site's stability and integrity. Through excavation and other construction activities, many adjacent archaeological remains were damaged or destroyed. For example, non-local gravel and other materials were used to fill in multiple areas, which disrupted the archaeological context. Also, the increased vehicle, 
aircraft, and pedestrian traffic in the area caused vibration and other damage to the standing ruins (Rush 2010b). A base located near Kirkuk, Iraq, also caused several instances of similar construction activities to disrupt the site of an ancient city, which was only noticed and recorded due to the volunteer efforts of a deployed Air Force First Sergeant whose civilian career was in the field of contract archaeology. His actions prevented further damage (Pinckney 2010).

All of these incidents came about due to a lack of awareness on the part of military planners about the important cultural, archaeological, and historical sites in the areas of operation. This type of damage, though not intentional, still harms both the culture of the host nation as well as the reputation of the U.S. military as a respectful, helpful, trustworthy organization Gibson 2009, 334; Kila 2011, 324; 2013, 33). This negative reputation can create a source of propaganda for use by enemies, and it also harms the military's international reputation with allies (Kila 2011; Rush 2010a).

Given the relatively recent shift in the nature of warfare from large-scale international battles to smaller intra-national conflicts and insurgencies, the nature of the military's protection of heritage sites must also change. This shift to the "new" form of warfare-suppressing insurgent groups and rebuilding a national government (such as in Iraq) - can no longer be overlooked.

These few brief examples are evidence of a string of failures in supporting protection of heritage sites in other countries, but there have also been some success stories in military heritage site protection efforts being moved forward. Building on the successes of the past and on recent attempts to resolve site and property protection crises, the U.S. military is poised to move beyond the missteps of the past to a more culturally conscious future.

\subsection{Historical successes}

Though a structured program is not currently in place for heritage site preservation in host nations, the U.S. Army does have some historical successes in the field. From World War II through the conflicts in Iraq and Afghanistan, there have been several instances which showcase the military's ability to perform its primary mission while also safeguarding or restoring cultural and natural heritage sites. There have been recent calls to emulate 
one of the most successful heritage site protection programs in modern military history-the Monuments, Fine Arts, and Archives (MFAA) section in the European theater of the Second World War.

The MFAA section was a collection of mostly British and American soldiers, better known as the Monuments Men, who were attached to units within Allied forces and who had the express objective of preserving what remained of Europe's architecture and art (Spirydowicz 2010, 15). These (mostly) officers were assigned to specific zones in Europe, and they were given duties based on their civilian careers such as conservators, curators, artists, museum professionals, and archivists. The assigned officer would enter an area only after it was secured entirely by Allied forces, with the express directive of protecting monuments from unnecessary damage or misuse during and after combat, arranging for emergency repairs to damaged monuments, recording thefts of works of art by the enemy, and collecting any evidence which might lead to their eventual recovery (Edsel 2009; Spirydowicz 2010, 17).

The MFAA became instrumental in the discovery, investigation, and repatriation of more than 600 repositories of art looted by the Nazi regime and subsequently found throughout Germany and Austria (Edsel 2009; Spirydowicz 2010). Many who served in the section did so after the main hostilities of the war had ceased, and their duties included accounting for, repairing, and returning the looted art and artifacts. These soldiers played an important role in the war, one that served to improve public opinion about the invading and occupying forces. With this multipurpose service, the MFAA can be considered both proactive and reactive in relation to cultural property, with their efforts encompassing both large sites and movable pieces of art. The MFAA as a section no longer exists, but some vestiges of it still remain within the U.S. Army's Civil Affairs section (Wegener 2010; Wegener and Otter 2008). Similar efforts have also been undertaken by other sections in the recent conflicts, most notably after the looting and damage to the National Museum of Iraq.

Colonel Matthew Bogdanos led the investigation into the looting of the National Museum of Iraq, using forensics and other criminal investigative methods in an attempt to ascertain who was responsible for the looting and to establish a credible list of what had been stolen (Bogdanos 2005a, 2005b, 2008). He volunteered for the duty immediately upon hearing of the event, especially in light of the blame being cast on U.S. forces. He 
worked quite successfully with Iraqi museum officials during the investigation and oversaw the return of thousands of looted artifacts through amnesty programs, community outreach, and networking with local people.

COL Bogdanos was also the first to publicly state the link between the insurgents in Iraq and the stolen antiquities market. During many raids performed by his team, they encountered weapons caches alongside illegally obtained artifacts from both the National Museum and other sites throughout Iraq. He repeatedly stated his belief that those who were willing to purchase looted antiquities in Europe or the Americas were, in essence, funding the insurgents that their own troops were fighting against in Iraq (Bogdanos 2008, 60). Similar to the looting of the National Museum, several other instances of damage to archaeological sites in Iraq and Afghanistan can be attributed to lack of awareness up and down the military's chain of command of the importance and location of heritage sites.

Dr. Laurie Rush, Cultural Resources Manager and Army Archaeologist at Fort Drum in New York, is attempting to remedy that lack of training and awareness in deploying troops by implementing several new programs (Rush 2010a, 2010b; Zeidler and Rush 2010, 73). She consistently points out that without this basic training and awareness of issues within heritage management and preservation, troops are unlikely to even consider it, let alone make it a priority in their strategic planning (Zeidler and Rush 2010, 73). Several programs in-theater, both overseas and domestically, have been piloted through Fort Drum. These programs appear successful in their initial phases.

One example of a successful program is a deck of playing cards that was developed for deployed troops in Iraq and Afghanistan. Each card featured information about local cultural heritage, important sites, heritage laws, and tips to help safeguard sites and artifacts (Zeidler and Rush 2010b, 78). Dr. Rush also created several training exercises at Fort Drum to better prepare deploying troops for encountering heritage sites abroad. These exercises included constructing replica archaeological sites in the midst of training areas so that troops could learn to identify and avoid such sites (Rush 2010b, 90) and opening an actual historic town site within Fort Drum's boundaries. Using the town site for training maneuvers teaches troops how to move within culturally sensitive areas without doing damage, but still accomplishing their mission (Rush 2010b, 91). It would 
greatly benefit the Army if other installations also implemented such programs to raise overall awareness of heritage site preservation, especially in light of the United States' 2008 ratification of the "Convention for the Protection of Cultural Property in the Event of Armed Conflict," held at the Hague in $1954 \cdot^{1}$

The United States became a signed party to the 1954 Hague Convention in 2008, possibly due in part to the extreme public pressure and disapproval of the treatment of cultural heritage sites during the ongoing conflict in Iraq. This ratification means the United States is now fully held to the guidelines and laws laid out within the convention, and it must abide by them or risk breaking what is considered accepted international law (Gerstenblith 2010). The Convention itself attempts to strike a balance between humanitarian and military requirements, allowing for the protection of cultural properties during armed conflict, but not being so restrictive that militaries are unable to perform their duties and effectively respond to threats (Chamberlain 2004, 23).

The basic starting point of the Convention is that preservation of cultural heritage is not solely a matter for the state that has it, but is a matter of international concern (Chamberlain 2004, 24). This acknowledgement leads to the concept of world heritage, and it heightens the importance of preserving the cultural and natural heritage sites of communities other than one's own. Many of the countries who are signatories are still in the process of fully domestically implementing the Hague Convention's guidelines and there is an ongoing legal and political concern and debate about the applicability of the Hague Convention to non-state entities such as insurgent or terrorist organizations (Gerstenblith 2010; Howe 2012). Clearly there is still work to be done in fully implementing and ensuring compliance to the Convention, but the progress is contributing to a rising level of awareness within military communities about heritage sites, which is hopefully contributing to less unintended harm at these sites (Gerstenblith 2010).

\footnotetext{
1 U.S. representatives to the Hague conference were involved in drafting the treaty and even signing it, but due to Cold War politics, it was not sent by President Dwight D. Eisenhower to the U.S. Senate for ratification. Following the end of the Cold War, President Bill Clinton sent it to a Senate committee for consideration in 1999. After hearings and testimony, the full Senate voted to ratify the main treaty on 25 September 2008.
} 
Unintended harm to heritage sites during conflicts and/or aerial strikes has been on a rapid decline of late due not only to improvements in targeting technology, but also to compiling fairly extensive no-strike lists before the strikes begin. Multiple agencies and researchers have contributed site locations to these lists to assist the military in planning and executing their actions, while avoiding adverse effects as much as possible during all phases of operation (Green 2010, 111). If possible when assembling nostrike lists, host nation experts have been consulted along with international researchers and available open-source data or satellite images (Green 2010, 112; Parcak 2010, 168).

The compilation of no-strike lists during the planning phases for recent conflicts has proved quite successful in avoiding damage to heritage sites. The U.S. military has acknowledged that this type of heritage site protection is necessary and has incorporated it into some of its planning processes. There is now a need for a similar proactive strategy for ground operations to match the forward planning of aerial assaults (Kila 2013; Rush 2012b). The ENSITE program can help to fill a significant portion of this need and provide a platform for recognition, avoidance, and protection of heritage sites during the deployed forces' maneuvers and infrastructure construction. 


\section{ENSITE}

To sustain itself as the world's premier land power, the U.S. Army needs the capability to support expeditionary forces by projecting a minimal basing footprint with reduced logistical burdens. Strategically siting Deployed Force Infrastructure (DFI) will allow the Army's expeditionary forces to rapidly respond and operate throughout the joint area of operations. Strategic conditions will be analyzed through the lens of eight operational environment variables, known by the abbreviation PMESII-PT with its variables listed here: political, military, economic, social, information, infrastructure, physical environment, and time (U.S. Army 2012).

The Army currently has neither a well-grounded methodology nor the tools to enable this strategic decision-making capability. Military decision makers require reliable information about the situational dynamics of the operational environment to anticipate the impacts that siting and operating DFI will have on the local context and conversely, to consider the effects of the site on the operation of the DFI. The capability to anticipate DFI's impacts in a local context becomes particularly important for engagement operations during which the DFI will have a longer duration of use and interaction with the local populace. An understanding of these potential impacts enables decision makers to evaluate implications of the effects of the DFI lifecycle in the pre-operational planning stage.

A DFI can be thought of as operating in an ecosystem that encompasses a local context comprised of physical environment, built environment, and sociocultural structures. The construction and operation of DFI can have local to global effects on the physical and sociocultural systems within this ecosystem. Identifying the effects of DFI on a context and considering how the effects may play out in possible courses of action is analogous to the process of conducting an environmental or social impact assessment, and is submitted to the Army's Intelligence Preparation of the Battlespace or the Joint Intelligence Preparation of the Operational Environment.

ENSITE provides military planners with the ability to remotely sense potential DFI locations through weighted algorithms based upon military planning factors. The research conducted for the ENSITE program creates an impact assessment methodology to operationalize the physical, ecological, and sociocultural attributes for transition into existing Programs of 
Records. The development of ENSITE's Qualitative Assessment Framework allows physical, ecological, and sociocultural environmental attributes to be spatially defined in support of the commander's intent.

Furthermore, research as part of ENSITE develops a statistical algorithm to classify physical, ecological, and sociocultural environmental attributes (Figure 1 and Figure 2).

Figure 1. Screenshot of ENSITE main dashboard (ERDC-CERL).

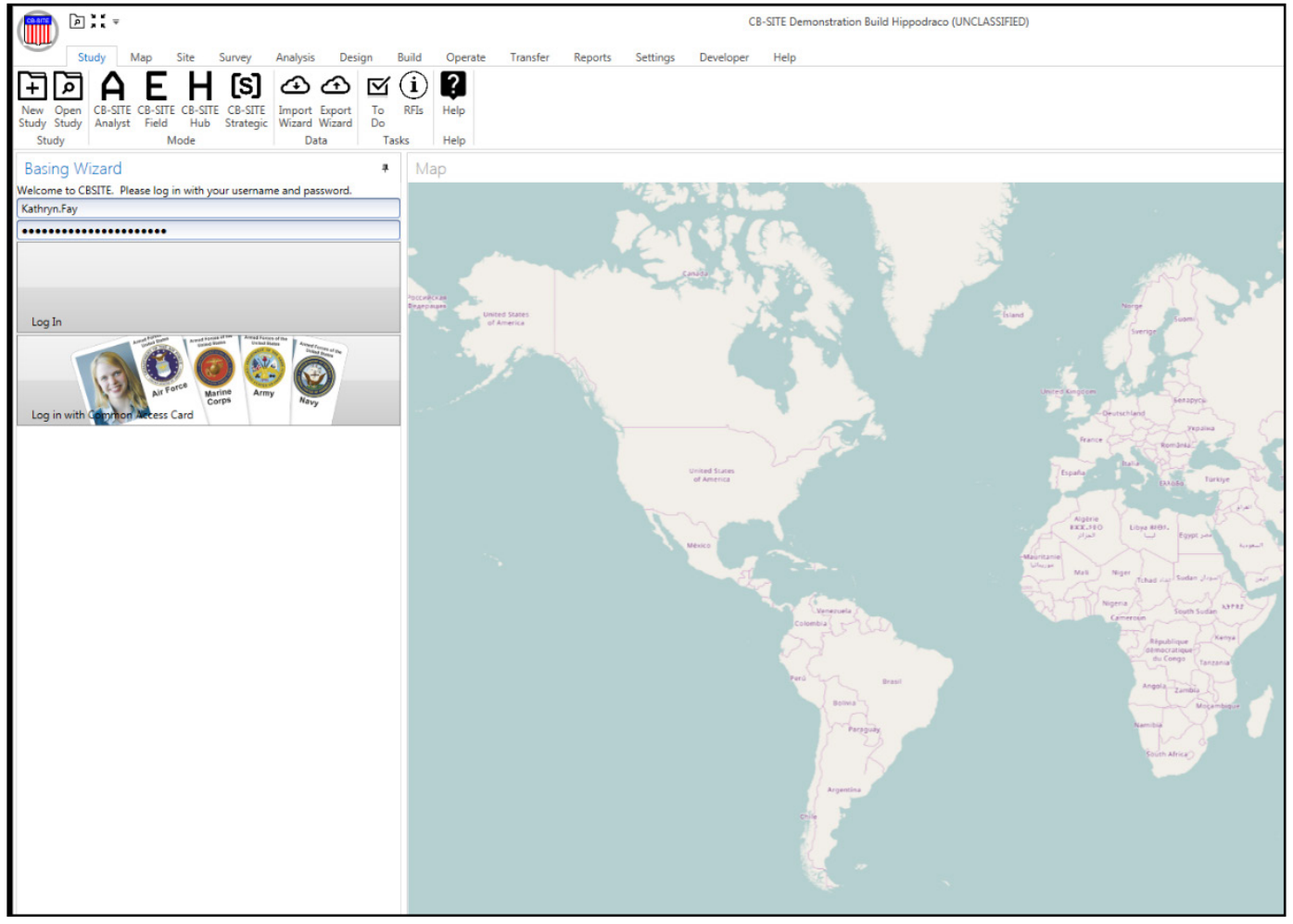


Figure 2. Screenshot of ENSITE initial process options for site-selection process, using Dhaka, Bangladesh, as a test area (ERDC-CERL).

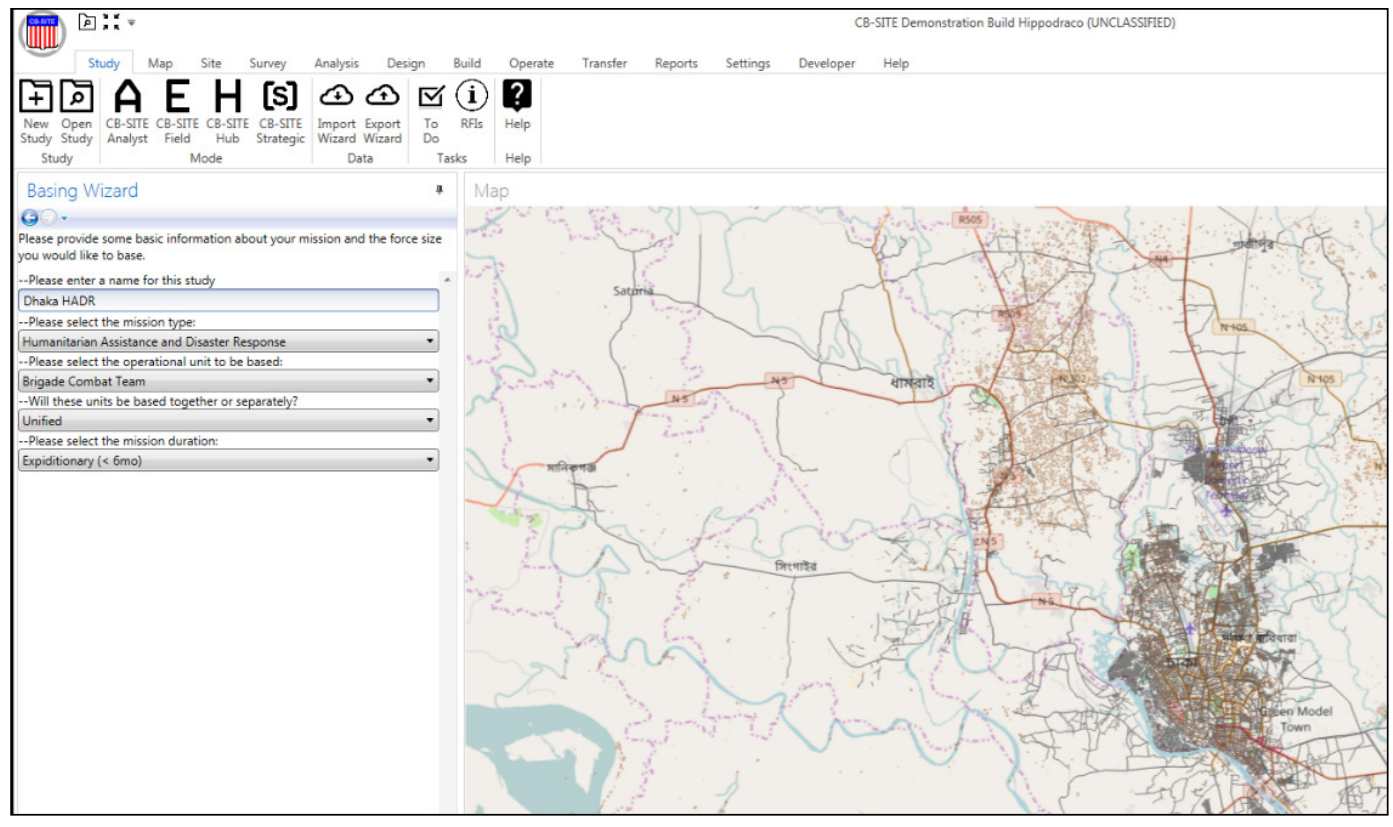

The protection of cultural and natural heritage sites must also be taken into account when doing any construction in a military environment, and the addition of the heritage sites map function within the ENSITE program fulfills this need. A search function has been created to data-mine open-source repositories for location information for cultural and natural heritage sites within the requested geographic area. This search currently uses data obtained from Open Street Map, the United Nations Environment Programme's Protected Planet database, and the United Nations Educational, Scientific and Cultural Organization's (UNESCO) World Heritage List. The use of the Protected Planet database and the World Heritage List assure that cultural or natural sites having major international or national recognition and protection are marked as no-build zones within the ENSITE program. Open Street Map provides a more specific accounting of known heritage sites, both those of historic value and those that are still in active use today.

A list of the types of sites that would be considered heritage sites within the ENSITE program, and thus be given "no-build zone" status, was created by the authors based on those sites listed in U.S. federal and international treaty laws as requiring protection during conflict (Table 1). These sites include historic buildings, nature preserves, museums, places of religious worship, and places that play a large part in the cultural identity of a 
population, such as art galleries, libraries, archives, cemeteries, and monuments. Location data for these types of sites is pulled from the open-source databases listed above for each requested regional area. Each of these sites is then allowed a one hundred meter buffer zone around it that is included as a no-build area (Figure 3). The inclusion of a buffer zone is common in domestic heritage preservation work and provides an additional layer of protection for sites from vibration damage, chemical or waste runoff, and potential weapons fire, among other types of potentially damaging occurrences.

Table 1. Some types of heritage sites included in the ENSITE program as protected, no-build areas.

\begin{tabular}{|ll|l|}
\hline \multicolumn{2}{|c|}{ Cultural Sites } & \multicolumn{1}{c|}{ Natural Sites } \\
\hline Museum & Auditorium or theater & Heritage landscape \\
\hline Library & Community center & Viewshed/viewpoint \\
\hline Archive & Shipwreck & $\begin{array}{l}\text { Nature preserve or } \\
\text { reserve }\end{array}$ \\
\hline Zoo or aquarium & Cemetery/graveyard & Park/playground \\
\hline $\begin{array}{l}\text { Ruin or other } \\
\text { archaeological site }\end{array}$ & $\begin{array}{l}\text { Observatory or } \\
\text { planetarium }\end{array}$ & National or regional park \\
\hline Public Art & Religious Building/Site & Wildlife sanctuary \\
\hline Monument & $\begin{array}{l}\text { Historical battlefield or } \\
\text { other historical site }\end{array}$ & $\begin{array}{l}\text { Botanical or other public } \\
\text { garden }\end{array}$ \\
\hline Stadium & Neighborhood & Protected area \\
\hline Mausoleum or Memorial & Building & Wetland \\
\hline
\end{tabular}

The potential for some heritage sites to not have their locations on any of the utilized open-source databases is acknowledged, especially archaeological sites which may have little or no extant remains above ground. This deficiency in location data must be accepted until more specific information may be made available and incorporated into the search. Most countries, including the United States, do not make public the complete list of known archaeological sites due to preservation and looting concerns. If allowed access in the future to such data, it could certainly be included within the ENSITE program. Other U.S. government organizations' heritage site data may also be included in the future, such as the no-strike lists compiled by the Defense Intelligence Agency, the U.S. Air Force, and the U.S. Committee of the Blue Shield. 
Figure 3. The metropolitan area of Dhaka, Bangladesh, used as a high population density test area for the identification and mapping of heritage sites within the ENSITE program. Identified heritage sites and their surrounding buffer zones are highlighted in red (ERDC-CERL).

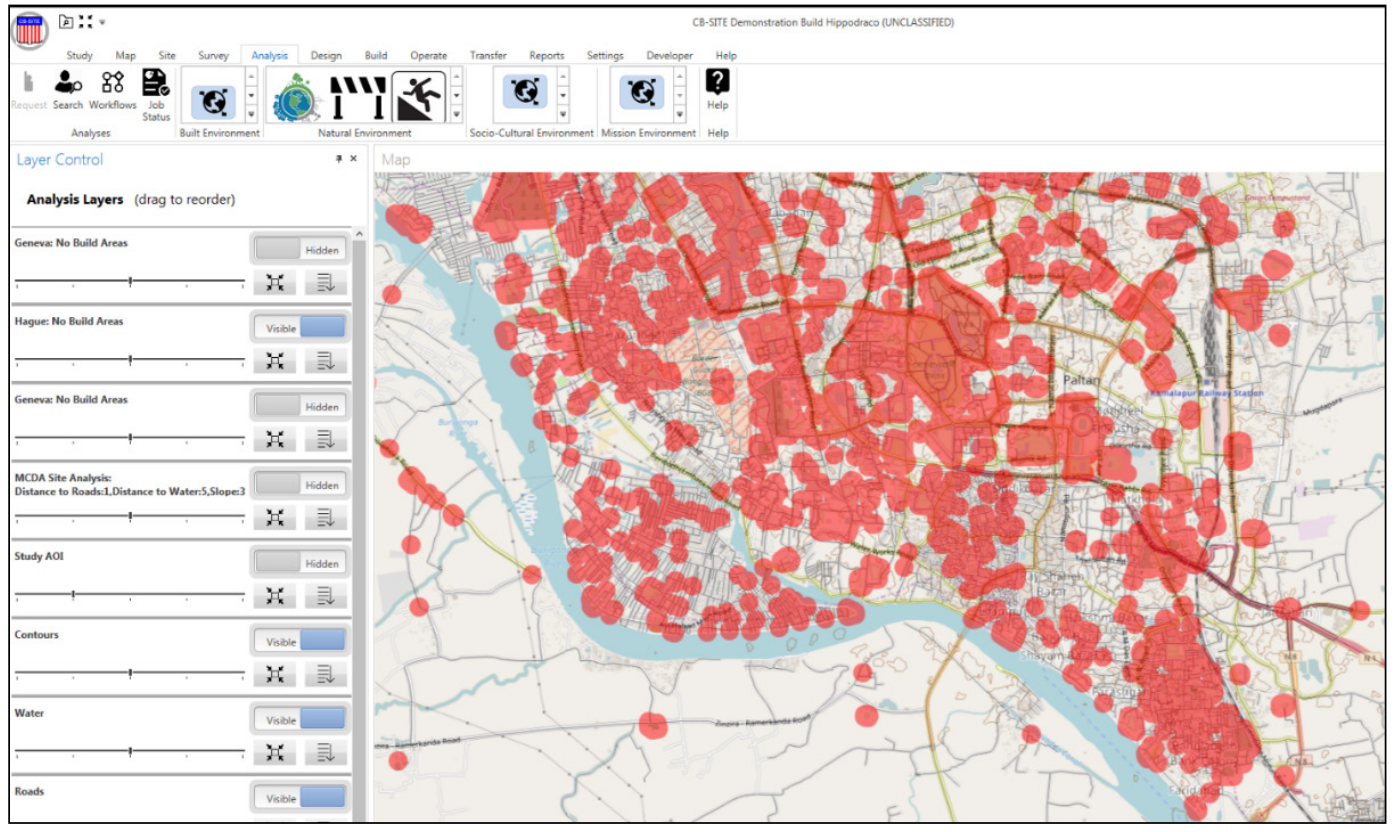

The inclusion of cultural and natural heritage site data into a construction database has the potential to avoid or mitigate potential damage caused by the building of DFI. As stated previously, this damage avoidance effort not only keeps the U.S. Army in accordance with international treaty laws, it also improves the reputation of the organization at home and abroad, and it further helps to earn the trust of local populations in areas of conflict. The ENSITE project fulfills an obvious need for the Army to become more aware of heritage sites abroad, and its development and use shows the Army's desire to become more proactive about protecting heritage sites along with the concerns, interests, and culture of the people those sites represent. 


\section{Future Research and Implementation}

In the future, the information base can be expanded for the heritage site section of ENSITE. Initially, ENSITE created a framework for the program with baseline data of known locations that researchers obtained from the open-source information websites of Open Street Map, Protected Planet, and UNESCO. It is acknowledged, however, that these website's datasets are not all-encompassing, especially regarding archaeological sites that do not exhibit extant surface remains.

The baseline data described above allows at least major and/or known sites to be immediately listed as protected, should the Army need to move into an area with little advance notice. With even a few weeks lead time, however, it would be possible for ENSITE project staff or program users to run the initial search and then engage the knowledge of subject-matter experts (SMEs) in the geographical area of Army interest, or if that is not possible, to engage with SMEs within the United States. This engagement would allow more sites to be added to the protected list, ahead of the building phase of Army mobilizations. In addition, ENSITE project staff hopes that additional sites will be recorded by soldiers in-country, and then that information will be added to ENSITE to further focus geographic specificity and coverage. It is acknowledged that it is logistically unlikely to ever record 100 percent of all cultural and natural heritage sites within any geographical area, but once the Army fully implements the ENSITE program, the software will allow protection of a much greater number of sites than in the past.

In the next phase of ENSITE's development, relevant cultural or natural heritage laws within each host nation could be applied to the mapping software. For instance, if a nation has a law that no building can be constructed within a 1,000-meter radius of a nature preserve, then that law would supersede the software's built-in 100-meter buffer for all heritage sites. The United States is legally and ethically bound by international treaty and our own laws to respect and follow the laws relevant to heritage sites within other nations when moving through them for military purposes, whether those purposes are combat- or humanitarian aid-related.

The ENSITE program is helping to fill an obvious need within the military system, especially for the Army and its primarily ground-based mission. 
Protection of cultural and natural heritage property must be taken seriously as a legitimate concern during military planning phases for any sort of troop-related movement, operation, or construction. Many individuals, both military and civilian, have called for greater attention to be paid to this issue within military regulations, structure, and training (Bodanos 2005a, 2005b, 2008; Green 2010; Jackson 2008, 54; Kila 2011, 324;.2012; 2013; Pinckney 2010; Rush 2012a, 2012b; Rush and Bogdanos 2009; Wegener 2010; Wegener and Otter 2008; Zeidler and Rush 2010).

Although reactive measures to damage have received attention and coverage after damage has already occurred, the Army needs better and more proactive measures for protecting cultural and national heritage property. Compiling no-strike lists for aerial campaigns has had a great measure of success in contributing to proactive protection during recent conflicts, and the heritage site function of the ENSITE program plans to become the successful counterpart for ground-based operations. 


\section{References}

Bahrani, Zainab. 2003. "Iraq's Cultural Heritage: Monuments, History, and Loss.” Art Journal 62(4): 10-17.

Bogdanos, Matthew. 2005a. 'The Casualties of War: The Truth about the Iraq Museum." American Journal of Archaeology 109(3): 477-526.

. 2005b. Thieves of Baghdad: One Marine's Passion for Ancient Civilizations and the Journey to Recover the World's Greatest Stolen Treasures. New York: Bloomsbury.

. 2008. "See No Evil: Museums, Art Collectors, and the Black Markets They Adore.” In Antiquities Under Siege: Cultural Heritage Protection After the Iraq War, edited by Lawrence Rothfield. Lanham, MD: AltaMira (of Rowman \& Littlefield Pub. Group).

Chamberlain, Kevin. 2004. War and Cultural Heritage: An Analysis of the 1954 Convention or the Protection of Cultural Property in the Event of Armed Conflict and its Two Protocols. Builth Wells, UK: Institute of Art and Law.

Edsel, Robert M., with Bret Witter. 2009. The Monuments Men: Allied Heroes, Nazi Thieves, and the Greatest Treasure Hunt in History. New York: Center Street.

Emberling, Geoff, and Katharyn Hanson. 2008. Catastrophe!: The Looting and Destruction of Iraq's Past. Oriental Institute Museum Publications No. 28. Chicago, IL: The University of Chicago.

Gerstenblith, Patty. 2009. "Archaeology in the Context of War: Legal Frameworks for Protecting Cultural Heritage during Armed Conflict." Archaeologies: Journal of the World Archaeological Congress 5(1): 18-31.

2010. 'The Obligations Contained in International Treaties of Armed Forces to Protect Cultural Heritage in Times of Armed Conflict.” In Archaeology, Cultural Property, and the Military, edited by Laurie Rush, 18-31. Woodbridge, Suffolk, UK: Boydell Press.

Gibson, McGuire. 2009. "Culture as Afterthought: US Planning and Non-planning in the Invasion of Iraq" Conservation and Management of Archaeological Sites 11(34): $333-339$.

Green, Paul R. 2010."Cultural Resources Data for Heritage Protection in Contingency Operations." In Archaeology, Cultural Property, and the Military, edited by Laurie Rush, 108-116. Woodbridge, Suffolk, UK: Boydell Press.

The Hague. "Convention for the Protection of Cultural Property in the Event of Armed Conflict.” Netherlands: The Hague, 1954.

Hallet, Michael. 2013. "Aiming to Miss: Engaging with the Targeting Process as a Means of Cultural Property Protection." In Cultural Heritage in the Crosshairs: Protection of Cultural Heritage During Conflict, edited by Joris D. Kila and James A. Zeidler. Biggleswade, Bedfordshire (UK): Brill. 
Howe, Zoë. 2012. "Can the 1954 Hague Convention Apply to Non-state Actors?: A Study of Iraq and Libya." Texas International Law Journal 47(2): 403-415.

Huot, Jean Louis. 2008. “The Importance of Iraq's Cultural Heritage.” In The Destruction of Cultural Heritage in Iraq, edited by Peter G. Stone and Joanne Farchakh Bajjaly. Rochester, NY: Boydell \& Brewer Inc..

Isakhan, Benjamin. 2013. "Heritage Destruction and Spikes in Violence: The Case of Iraq.” In Cultural Heritage in the Crosshairs: Protection Cultural Heritage During Conflict, edited by Joris D. Kila and James A. Zeidler, 219-247. Leiden, Netherlands: Koninklijke Brill.

Jackson, Richard (Dick). 2008. "Cultural Property Protection in Stability Operations." The Army Lawyer. Department of the Army Pamphlet 27-50-425. October 2008: 47-57.

Kila, Joris D. 2011. "Cultural Property Protection in the Context of Military Operations: The Case of Uruk, Iraq." Conservation and Management of Archaeological Sites 13(4): 311-333.

2012. Heritage Under Siege: Military Implementation of Cultural Property Protection Following the 1954 Hague Convention. Leiden, Netherlands: Koninklijke Brill.

. 2013. "Military Involvement in Cultural Property Protection as Part of Preventive Conservation." In Cultural Heritage in the Crosshairs: Protection of Cultural Heritage During Conflict, edited by Joris D. Kila and James A. Zeidle, 9-50. Leiden, Netherlands: Knoninklidjke Brill.

Kila, Joris D., and Christopher V. Herndon. 2014. "Military Involvement in Cultural Property Protection: An Overview." Joint Forces Quarterly 74 ( $3^{\text {rd }}$ Quarter, July): 116-123.

Parcak, Sarah. 2010. "Preserving Global Heritage from Space in Times of War' Operations." In Archaeology, Cultural Property, and the Military, edited by Laurie Rush, 167-176. Woodbridge, Suffolk, UK: Boydell Press.

Pinckney, Darrell C. 2010. "Time Not on My Side: Cultural Resource Management in Kirkuk, Iraq." In Archaeology, Cultural Property, and the Military, edited by Laurie Rush, 117-125. Woodbridge, Suffolk, UK: Boydell Press.

Rush, Laurie. 2010a. "Dealing the Heritage Hand: Establishing a U.S. Department of Defense Cultural Property Protection Program for Global Operations." In Archaeology, Cultural Property, and the Military, edited by Laurie Rush. Woodbridge, Suffolk, UK: Boydell Press. . 2010b. "Teaching Cultural Property Protection in the Middle East: The Central Command Historical/Cultural Advisory Group and International Efforts." In Archaeology, Cultural Property, and the Military, edited by Laurie Rush. Woodbridge, Suffolk, UK: Boydell Press.

2012a. "Cultural Property Protection as a Force Multiplier in Stability Operations: World War II Monuments Officers Lessons Learned.” Military Review March-April: 36-43. 
2012b. "Working with the Military to Protect Archaeological Sites and Other Forms of Cultural Property.” World Archaeology 44(3): 359-377.

Rush, Laurie, and Matthew Bogdanos. 2009. "Protecting the Past to Secure the Future: The Strategic Value of Heritage Training." Joint Forces Quarterly 53 (2nd Quarter): 126-127.

Spirydowicz, Krysia. 2010. "Rescuing Europe's Cultural Heritage: The Role of the Allied Monuments Officers in World War II.” In Archaeology, Cultural Property, and the Military, edited by Laurie Rush. Woodbridge, Suffolk, UK: Boydell Press.

Stone, Peter. 2009. "Protecting Cultural Heritage in Times of Conflict: Lessons from Iraq." Archaeologies: Journal of the World Archaeological Congress 5(1): 3238. doi:10.1007/s11759-008-9093-5.

U.S. Army. August 2012. Operational Environments to 2028: The Strategic Environment for Unified Land Operations. Washington, DC: U.S. Army Training and Doctrine Command G-2.

Van der Auwera, Sigrid. 2013a. "International Law and the Protection of Cultural Property in the Event of Armed Conflict: Actual Problems and Challenges." The Journal of Arts Management, Law, and Society 43(4): 175-190.

. 2013b. "UNESCO and the Protection of Cultural Property during Armed Conflict.” International Journal of Cultural Policy 19(1): 1-19.

.2014. "Culture for Development and the UNESCO Policy on the Protection of Cultural Property during Armed Conflict.” International Journal of Cultural Policy 20(3): 245-260.

Wegener, Corine. 2010. "U.S. Army Civil Affairs: Protecting Cultural Property, Past and Future." In Archaeology, Cultural Property, and the Military, edited by Laurie Rush. Woodbridge, Suffolk, UK: The Boydell Press.

Wegener, Corine, and Marjan Otter. 2008. "Cultural Property at War: Protecting Heritage during Armed Conflict.” The Getty Conservation Institute Newsletter 23, 1.

White, Cheryl, and Thomas Livoti. 2013. "Preserving Cultural Heritage in Time of Conflict: A Tool for Counterinsurgency." In Cultural Heritage in the Crosshairs: Protection of Cultural Heritage During Conflict, edited by Joris D. Kila and James A. Zeidler, 195-218. Leiden, Netherlands: Knoninklidjke Brill.

Zeidler, James, and Laurie Rush. 2010. "In-Theatre Soldier Training through Cultural Heritage Playing Cards: A U.S. Department of Defense Example.” In Archaeology, Cultural Property, and the Military, edited by Laurie Rush, 73-85. Woodbridge, Suffolk, UK: The Boydell Press. 


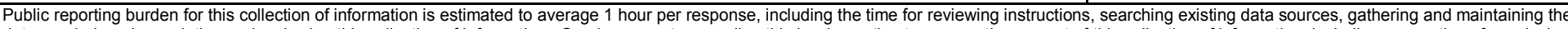

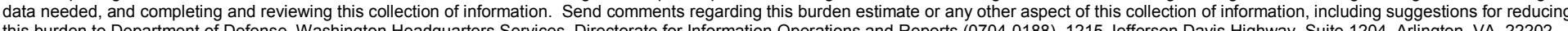

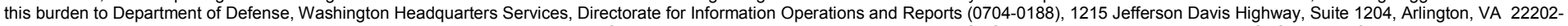

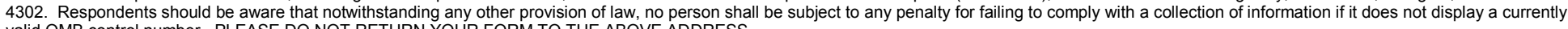
valid OMB control number. PLEASE DO NOT RETURN YOUR FORM TO THE ABOVE ADDRESS.
1. REPORT DATE (DD-MM-YYYY)
2. REPORT TYPE
July 2017
Final
3. DATES COVERED (From - To)

4. TITLE AND SUBTITLE

Endangered Cultural Heritage: Global Mapping of Protected and Heritage Sites

5a. CONTRACT NUMBER

5b. GRANT NUMBER

$\mathrm{T} 45$

6. AUTHOR(S)

Kathryn O. Fay and George W. Calfas

5d. PROJECT NUMBER

455009

5e. TASK NUMBER

5f. WORK UNIT NUMBER

7. PERFORMING ORGANIZATION NAME(S) AND ADDRESS(ES)

U.S. Army Engineer Research and Development Center (ERDC)

Construction Engineering Research Laboratory (CERL) NUMBER

PO Box 9005

ERDC/CERL MP-17-1

Champaign, IL 61826-9005

\section{SPONSORING / MONITORING AGENCY NAME(S) AND ADDRESS(ES)}

Assistant Secretary of the Army for

Acquisition, Logistics, and Technology

103 Army Pentagon

Washington, DC 20314-1000

ASA(ALT) NUMBER(S)

12. DISTRIBUTION / AVAILABILITY STATEMENT

Approved for public release. Distribution is unlimited.

\section{SUPPLEMENTARY NOTES}

\section{ABSTRACT}

Through its many global missions, the United States Army has not always recognized nor allocated sufficient resources to protect cultural heritage sites in active military zones. This pattern is changing, however, especially as a result of incidents that occurred during antiterrorism military missions in Iraq and Afghanistan. To change that pattern, the Engineer Research and Development Center of the U.S. Army Corps of Engineers is designing an interactive mapping program that provides information on possible suitable locations for future military movement and campsites. As part of that work, and in light of past frictions between military actions and cultural heritage preservation, both cultural anthropologists and archaeologists have contributed information about the locations of sacred sites, heritage landscapes, archaeological remains, and other locations of cultural and religious importance. These locations are then noted within the mapping program as areas that are culturally unsuitable for military movement or settlement, similar to noting areas that would be logistically or environmentally unsuitable. This paper discusses the project and its plans for implementation, in hopes of decoupling the past link between military action and unintentional damage or destruction of cultural heritage sites as well as expanding the knowledge base on these issues in the military community.

\section{SUBJECT TERMS}

Digital mapping; Cultural property_-Preservation; United States--Armed Forces; ENSITE, Contingency Basing

\section{SECURITY CLASSIFICATION OF:}

a. REPORT Unclassified

\section{b. ABSTRACT} Unclassified

17. LIMITATION
OF ABSTRACT
UU

\begin{tabular}{|c|} 
18. NUMBER \\
OF PAGES
\end{tabular}

5c. PROGRAM ELEMENT NUMBER

8. PERFORMING ORGANIZATION REPORT

10. SPONSOR/MONITOR'S ACRONYM(S)

11. SPONSOR/MONITOR'S REPORT

GRAM ELEMENT NUMBER
KECT NUMBER
KK UNIT NUMBER
CERMING ORGANIZATION REPORT
CERL MP-17-1
ALT)
BSOR/MONITOR'S REPORT
MER(S)

9a. NAME OF RESPONSIBLE PERSON

19b. TELEPHONE NUMBER (include area code) 